\title{
Comparison of Different Mass Spectrometry Workflows for the Proteomic Analysis of Tear Fluid
}

\author{
Garrett Jones ${ }^{1}$, Tae Jin Lee ${ }^{1}$, Joshua Glass ${ }^{1}$, Grace Rountree ${ }^{1}$, Lane Ulrich ${ }^{2}$, Amy Estes ${ }^{2}$, Mary Sezer ${ }^{2}$, \\ Wenbo Zhi ${ }^{1}$, Shruti Sharma ${ }^{1,2}$ and Ashok Sharma ${ }^{1,2,3, * \mathbb{B}}$
}

check for

updates

Citation: Jones, G.; Lee, T.J.; Glass, J.; Rountree, G.; Ulrich, L.; Estes, A.; Sezer, M.; Zhi, W.; Sharma, S. Sharma, A. Comparison of Different Mass Spectrometry Workflows for the Proteomic Analysis of Tear Fluid. Int J. Mol. Sci. 2022, 23, 2307. https:// doi.org/10.3390/ijms23042307

Academic Editor: Settimio Rossi

Received: 23 December 2021

Accepted: 15 February 2022

Published: 19 February 2022

Publisher's Note: MDPI stays neutral with regard to jurisdictional claims in published maps and institutional affiliations.

Copyright: (C) 2022 by the authors. Licensee MDPI, Basel, Switzerland. This article is an open access article distributed under the terms and conditions of the Creative Commons Attribution (CC BY) license (https:// creativecommons.org/licenses/by/ $4.0 /)$.
1 Center for Biotechnology and Genomic Medicine, Medical College of Georgia, Augusta University, Augusta, GA 30912, USA; garjones@augusta.edu (G.J.); talee@augusta.edu (T.J.L.); josglass@augusta.edu (J.G.); grountree@augusta.edu (G.R.); wzhi@augusta.edu (W.Z.); shsharma@augusta.edu (S.S.)

2 Department of Ophthalmology, Medical College of Georgia, Augusta University, Augusta, GA 30912, USA; lulrich@augusta.edu (L.U.); aestes@augusta.edu (A.E.); msezer@augusta.edu (M.S.)

3 Department of Population Health Sciences, Medical College of Georgia, Augusta University, Augusta, GA 30912, USA

* Correspondence: assharma@augusta.edu

\begin{abstract}
The tear film is a multi-layer fluid that covers the corneal and conjunctival epithelia of the eye and provides lubrication, nutrients, and protection from the outside environment. Tear fluid contains a high concentration of proteins and has thus been recognized as a potential source of biomarkers for ocular disorders due to its proximity to disease sites on the ocular surface and the noninvasive nature of its collection. This is particularly true in the case of dry eye disease, which directly impacts the tear film and its components. Proteomic analysis of tear fluid is challenging mainly due to the wide dynamic range of proteins and the small sample volumes. However, recent advancements in mass spectrometry have revolutionized the field of proteomics enabling unprecedented depth, speed, and accuracy, even with small sample volumes. In this study using the Orbitrap Fusion Tribrid mass spectrometer, we compared four different mass spectrometry workflows for the proteomic analysis of tear fluid collected via Schirmer strips. We were able to establish a method of in-strip protein digestion that identified $>3000$ proteins in human tear samples from 11 healthy subjects. Our method offers a significant improvement in the number of proteins identified compared to previously reported methods without pooling samples.
\end{abstract}

Keywords: tear film; proteomics; biomarkers; dry eye disease; ocular surface; mass spectrometry

\section{Introduction}

The tear film is a 2-6 $\mu \mathrm{m}$ stratified fluid, composed of mucoaqueous and lipid layers, that covers the corneal and conjunctival epithelia of the ocular surface. The mucoaqueous layer contains mucin and aqueous components, with mucin concentration decreasing along a gradient from the epithelium towards the aqueous layer. The mucins of the innermost layer extend large hydrophilic glycans to form the ocular surface glycocalyx [1]. The outermost layer of the tear film is a thin lipid layer that prevents evaporation of the mucoaqueous layer $[2,3]$. Proteins and lipids of the tear film safeguard the eye through anti-inflammatory, antioxidant, and antimicrobial activities [4-7]. Under healthy conditions, tears also provide nourishment to the apical epithelial cells and lubrication to the ocular surface to remove debris and prevent abrasion [2]. Insufficient secretion of the aqueous or lipid components of tears, laser eye surgery, and inflammatory pathologies, such as Sjögren's syndrome, can result in tear film disruption, leaving the eye more vulnerable to infection and inflammation [8,9]. Thus, the integrity of this film is necessary for maintaining normal vision and preventing ocular damage. 
Dry eye disease (DED) is a multifactorial disease of the ocular surface in which hyperosmolarity and instability of the tear film trigger inflammation, inducing a positive feedback loop of disease progression that eventually leads to corneal abrasions and ulceration [10]. Although the disease impacts both vision and quality of life, diagnosis of DED remains highly subjective and difficult due to an inconsistent correlation between symptom onset and clinical signs, as well as the absence of definitive diagnostic biomarkers [11-13]. Tear proteins are a potential source for identification of biomarkers for diagnosing and monitoring DED and its underlying pathophysiology [14-18].

In the past, proteomic analysis of tear fluid was challenging due to its small volume. However, recent technological advancements in mass spectrometry, such as the Orbitrap ion trap mass analyzer, have increased the depth, speed, and sensitivity of protein identification $[17,19,20]$. Beam-type collisional dissociation fragmentation techniques, such as collision-induced dissociation (CID) and higher-energy collisional dissociation (HCD), allow for high confidence identification of peptides, as well as their potential post-translational modifications [21]. These improvements allow for the precise and highthroughput proteomic profiling of small sample volumes, making it the ideal method for the identification of proteins and peptides in the tear film. To provide high-value proteomic data from tears, rigorous testing of tear protein processing methods coupled with mass spectrometry analysis is required. In this study, we compared four different workflows for the analysis of the tear proteome using mass spectrometry (Figure 1).

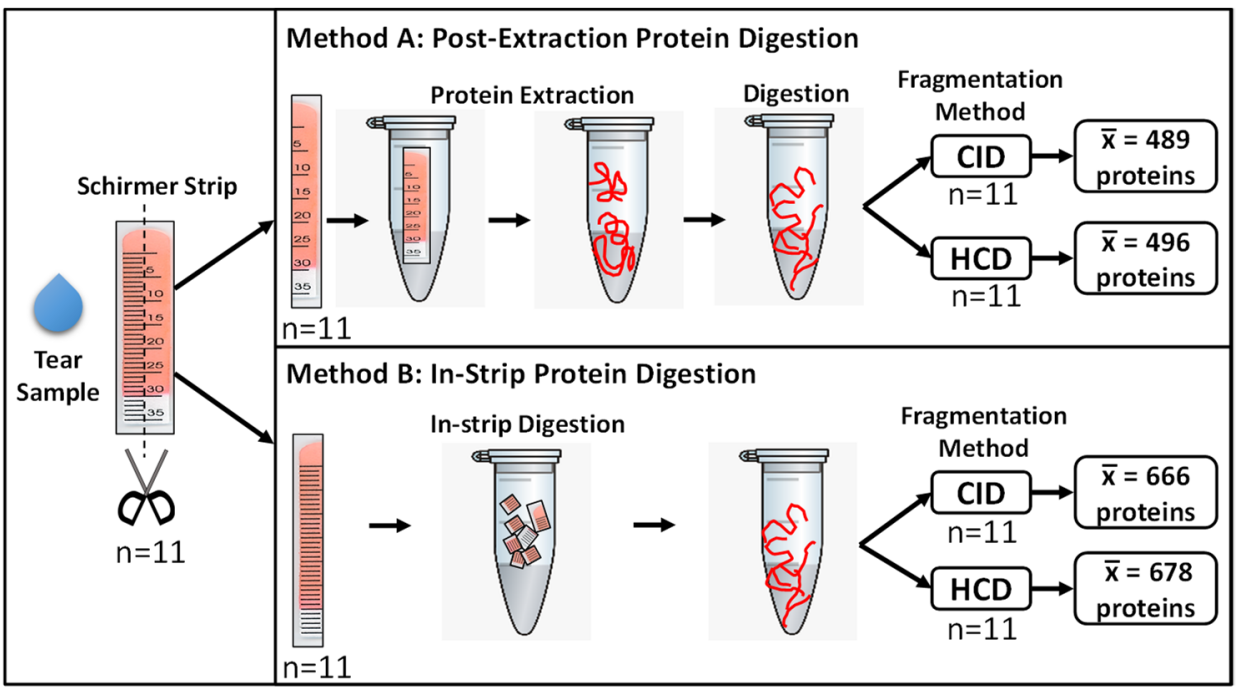

Figure 1. Comparison of two extraction methods (Method A and B) and two fragmentation methods (CID and HCD) for tear fluid processing. Tear fluid was collected using Schirmer strips $(n=11)$, and each strip was cut longitudinally into two equal parts. In Method A, proteins were first extracted, and Schirmer strips were removed by filter-aided centrifugation prior to digestion. In Method B, Schirmer strips were cut into $5 \mathrm{~mm}$ pieces, and in-strip protein digestion was performed. Digested products from each method then underwent LC-MS/MS analysis using both collision-induced dissociation (CID) and higher-energy collisional dissociation (HCD) fragmentation techniques. The average number of unique proteins $(\bar{x})$ identified per sample using each workflow is displayed.

\section{Results}

Tear samples were collected from 11 healthy subjects using Schirmer strips. The demographic information of the subjects is detailed in Table 1. A total of four analysis workflows, including two distinct protein digestion methods (post-extraction protein digestion and in-strip protein digestion) and two fragmentation techniques (CID and HCD), were compared. 
Table 1. Demographic characteristics of healthy subjects included in this study.

\begin{tabular}{cccc}
\hline Sample ID & Age & Sex & Race \\
\hline S1 & 27 & $\mathrm{~F}$ & White \\
S2 & 50 & $\mathrm{~F}$ & Other \\
S3 & 30 & $\mathrm{~F}$ & Other \\
S4 & 22 & $\mathrm{M}$ & White \\
S5 & 40 & $\mathrm{M}$ & Other \\
S6 & 27 & $\mathrm{~F}$ & White \\
S7 & 21 & $\mathrm{M}$ & White \\
S8 & 45 & $\mathrm{~F}$ & Other \\
S9 & 25 & $\mathrm{~F}$ & White \\
S10 & 26 & $\mathrm{~F}$ & White \\
S11 & 22 & & White \\
\hline
\end{tabular}

\subsection{In-Strip Protein Digestion Identifies More Proteins Than Post-Extraction Protein Digestion}

Post-extraction protein digestion (Method A) identified an average of $489 \pm 90$ unique proteins per sample after CID fragmentation and $496 \pm 85$ unique proteins per sample after HCD fragmentation. In-strip protein digestion (Method B) identified an average of $666 \pm 161$ unique proteins per sample when CID fragmentation was used and $678 \pm 180$ per sample when HCD fragmentation was used (Figure 2A). Thus, in-strip protein digestion allows for the identification of significantly more proteins using either CID ( $p$-value $=0.0160)$ or HCD $(p$-value $=0.0203)$ fragmentation. Similar trends were observed at the peptide level (Figure 2B). In-strip protein digestion identified significantly more unique peptides when paired with both CID $(1720 \pm 543$ vs. $1167 \pm 302 ; p$-value $=0.0266)$ and HCD $(1735 \pm 567$ vs. $1155 \pm 264 ; p$-value $=0.0185)$ fragmentation. There were no significant differences between the number of unique proteins or peptides identified via HCD and CID fragmentation when the same protein digestion method was used.
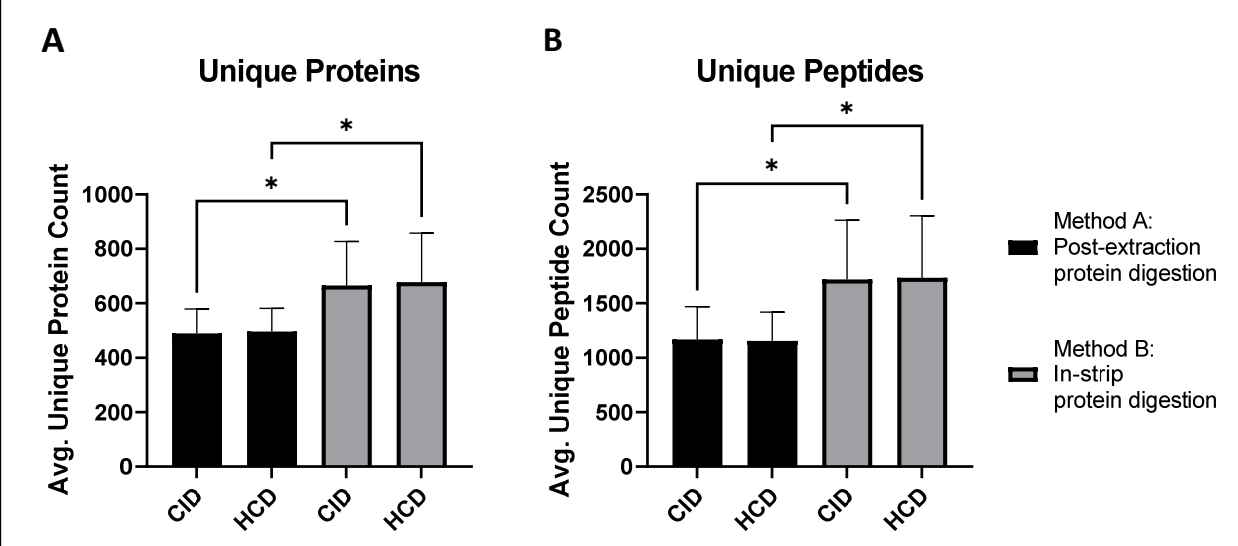

Figure 2. In-strip protein digestion (Method B) provides a significant increase in both protein and peptide yield compared to post-extraction protein digestion (Method A) in tear fluid samples. The average protein and peptide counts per sample identified in all four workflows were compared via two-way ANOVA with Tukey's correction. (A) Method B identified more proteins than Method A when paired with both CID and HCD fragmentation. (B) In-strip protein digestion also identified more peptides than post-extraction digestion following both CID and HCD fragmentation. Results are expressed as means $\pm \mathrm{SD} ; n=11$ /group; * $p$-value $<0.05$.

\subsection{Proteomic Profiling of Tear Samples}

The average protein levels, quantified by the number of peptide-spectrum matches (PSMs), were plotted against the proportion of samples in which they were detected, showing a positive correlation (Figure 3). The total unique proteins identified using the 
four different workflows are compared in Table 2. Based on their relative occurrence, these proteins were categorized into four groups: high (present in $>75 \%$ of samples), medium (present in $50-75 \%$ of samples), low (present in $25-50 \%$ of samples), or rare (present in 5-25\% of samples). A total of 3370 unique proteins were identified in the tear samples subjected to in-strip protein digestion and HCD fragmentation (high, $n=182$; medium, $n=147$; low, $n=373$; and rare, $n=2668$ ). Since this workflow identified the greatest number of unique proteins, these 3370 unique proteins were further examined using bioinformatics approaches to determine the characteristics of the proteome of human tear film. The 50 most abundant proteins detected using in-strip protein digestion and HCD fragmentation are listed in Table 3.

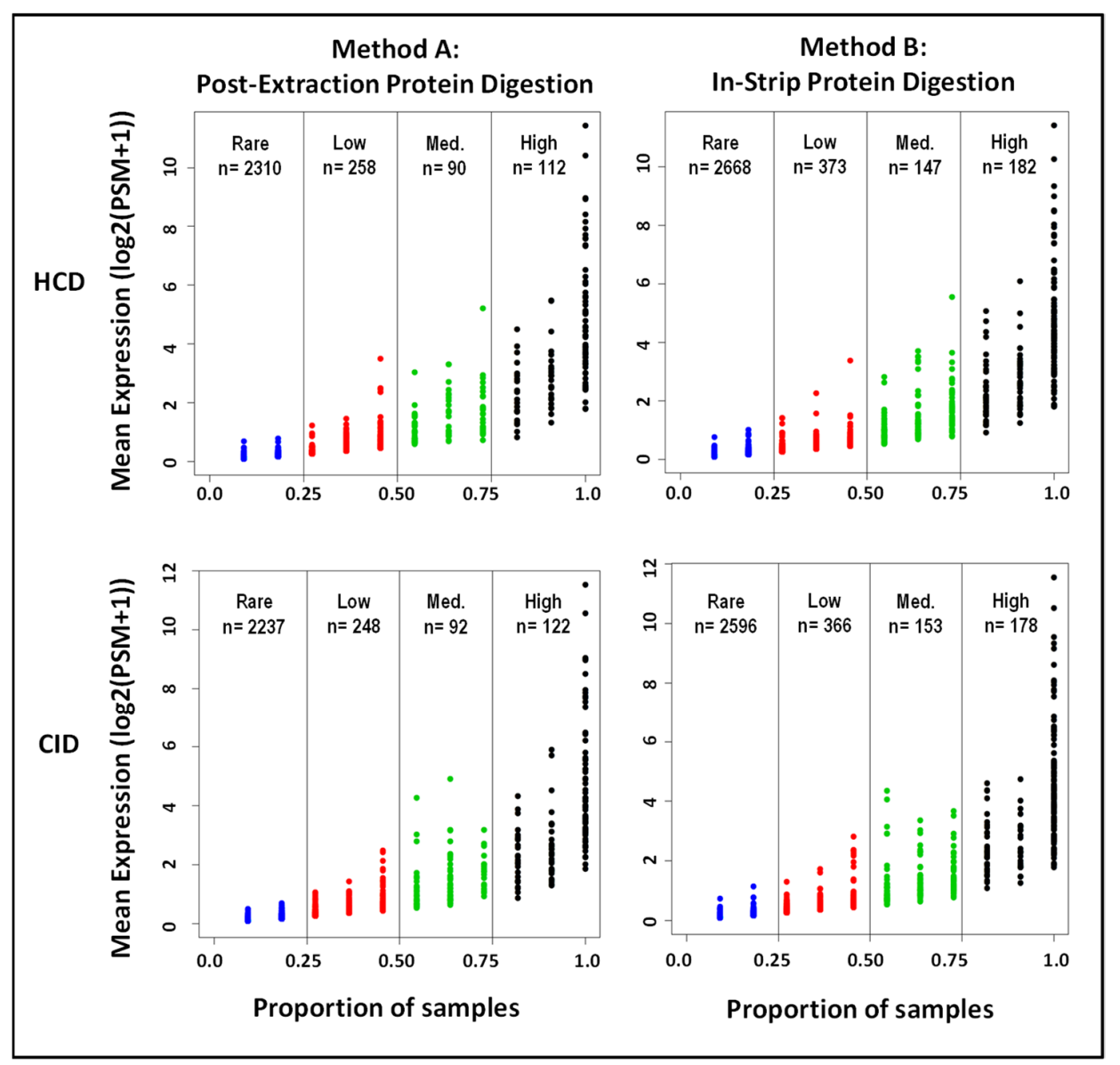

Figure 3. Distribution of mean protein expression by sample proportion in the four different workflows. Peptide-spectrum matches (PSMs) from the 11 tear samples were $\log 2$ transformed for each digestion and fragmentation method performed to compare differences in mean protein expression between workflows. Further, proteins detected in the 11 samples were proportionally assessed and subdivided into four categories based on trends of detection for each method: High (shown in black; detected in $>75 \%$ of samples), Medium (shown in green; detected in 50-75\%), Low (shown in red; detected in $25-50 \%$ ), and Rare (shown in blue; detected in 5-25\%).

Table 2. Total number of unique proteins identified in tear samples using four different workflows.

\begin{tabular}{|c|c|c|c|c|}
\hline \multirow{2}{*}{ Number of Unique Proteins Identified } & \multicolumn{2}{|c|}{ Method A } & \multicolumn{2}{|c|}{ Method B } \\
\hline & CID & HCD & CID & HCD \\
\hline High (detected in $>75 \%$ of samples) & 122 & 112 & 178 & 182 \\
\hline Medium (detected in $50-75 \%$ of samples) & 92 & 90 & 153 & 147 \\
\hline Low (detected in $25-50 \%$ of samples) & 248 & 258 & 366 & 373 \\
\hline Rare (detected in $5-25 \%$ of samples) & 2237 & 2310 & 2596 & 2668 \\
\hline Total & 2699 & 2770 & 3293 & 3370 \\
\hline
\end{tabular}


Table 3. Top 50 proteins identified in tear samples using in-strip protein digestion and HCD fragmentation.

\begin{tabular}{|c|c|c|c|c|}
\hline S. No. & UniProt ID & Gene Symbol & Description & Mean PSM \\
\hline 1 & P02788 & LTF & Lactotransferrin & 2802.91 \\
\hline 2 & P31025 & LCN1 & Lipocalin-1 & 1300.64 \\
\hline 3 & P02768 & $A L B$ & Albumin & 874.18 \\
\hline 4 & P12273 & PIP & Prolactin-inducible protein & 572.46 \\
\hline 5 & P01876 & IGHA1 & Immunoglobulin heavy constant alpha 1 & 386.19 \\
\hline 6 & P61626 & LYZ & Lysozyme C & 380.45 \\
\hline 7 & P01833 & PIGR & Polymeric immunoglobulin receptor & 275.36 \\
\hline 8 & Q9GZZ8 & $L A C R T$ & Extracellular glycoprotein lacritin & 263.91 \\
\hline 9 & P01834 & IGKC & Immunoglobulin kappa constant & 230.09 \\
\hline 10 & P0DOX2 & IGA2 & Immunoglobulin alpha-2 heavy chain & 212.87 \\
\hline 11 & P25311 & AZGP1 & Zinc-alpha-2-glycoprotein & 203.00 \\
\hline 12 & P0DOX7 & IGK & Immunoglobulin kappa light chain & 189.36 \\
\hline 13 & P01036 & CST4 & Cystatin-S & 185.90 \\
\hline 14 & O75556 & $S C G B 2 A 1$ & Mammaglobin-B & 137.72 \\
\hline 15 & Q16378 & PRR4 & Proline-rich protein 4 & 130.54 \\
\hline 16 & P01037 & CST1 & Cystatin-SN & 115.40 \\
\hline 17 & P19013 & KRT4 & Keratin, type II cytoskeletal 4 & 100.11 \\
\hline 18 & Q99935 & OPRPN & Opiorphin prepropeptide & 97.72 \\
\hline 19 & P60709 & $A C T B$ & Actin, cytoplasmic 1 & 97.63 \\
\hline 20 & P06733 & ENO1 & Alpha-enolase & 96.63 \\
\hline 21 & P04083 & ANXA1 & Annexin A1 & 95.45 \\
\hline 22 & Q9UGM3 & $D M B T 1$ & Deleted in malignant brain tumors 1 protein & 86.00 \\
\hline 23 & P01024 & C3 & Complement C3 & 80.54 \\
\hline 24 & P02787 & TF & Serotransferrin & 78.72 \\
\hline 25 & B9A064 & IGLL5 & Immunoglobulin lambda-like polypeptide 5 & 76.11 \\
\hline 26 & Q8N3C0 & ASCC3 & Activating signal cointegrator 1 complex subunit 3 & 73.45 \\
\hline 27 & P0DOX5 & IGG1 & Immunoglobulin gamma-1 heavy chain & 73.00 \\
\hline 28 & P0DOY2 & IGLC2 & Immunoglobulin lambda constant 2 & 70.18 \\
\hline 29 & P13646 & KRT13 & Keratin, type I cytoskeletal 13 & 70.11 \\
\hline 30 & P08727 & KRT19 & Keratin, type I cytoskeletal 19 & 66.00 \\
\hline 31 & P13647 & KRT5 & Keratin, type II cytoskeletal 5 & 56.00 \\
\hline 32 & P09211 & GSTP1 & Glutathione S-transferase P & 51.18 \\
\hline 33 & P68032 & ACTC1 & Actin, alpha cardiac muscle 1 & 48.10 \\
\hline 34 & P09228 & CST2 & Cystatin-SA & 47.71 \\
\hline 35 & P01860 & IGHG3 & Immunoglobulin heavy constant gamma 3 & 47.14 \\
\hline 36 & P14618 & PKM & Pyruvate kinase PKM & 46.54 \\
\hline 37 & P01591 & JCHAIN & Immunoglobulin J chain & 46.00 \\
\hline 38 & P98160 & HSPG2 & Heparan sulfate proteoglycan core protein & 45.72 \\
\hline 39 & P07355 & ANXA2 & Annexin A2 & 44.81 \\
\hline 40 & P0DOX6 & IGM & Immunoglobulin mu heavy chain & 44.28 \\
\hline 41 & P21980 & TGM2 & Protein-glutamine gamma-glutamyltransferase 2 & 43.00 \\
\hline 42 & P01871 & IGHM & Immunoglobulin heavy constant mu & 41.90 \\
\hline 43 & P30740 & SERPINB1 & Leukocyte elastase inhibitor & 40.54 \\
\hline 44 & P98088 & MUC5AC & Mucin-5AC & 40.33 \\
\hline 45 & P02538 & KRT6A & Keratin, type II cytoskeletal 6A & 40.33 \\
\hline 46 & P00450 & $C P$ & Ceruloplasmin & 40.18 \\
\hline 47 & P00352 & $A L D H 1 A 1$ & Aldehyde dehydrogenase 1A1 & 40.18 \\
\hline 48 & P01861 & IGHG4 & Immunoglobulin heavy constant gamma 4 & 40.00 \\
\hline 49 & P01859 & IGHG2 & Immunoglobulin heavy constant gamma 2 & 37.90 \\
\hline 50 & P08729 & KRT7 & Keratin, type II cytoskeletal 7 & 37.14 \\
\hline
\end{tabular}

\subsection{Major Protein Families Identified in Human Tear Samples}

Several major protein families are over-represented in the proteomic profile of human tear samples, including immunoglobulins (61 proteins), keratins (26 proteins), complements (17 proteins), myosins (15 proteins), apolipoproteins (11 proteins), heat shock proteins (10 proteins), protein s100 family (9 proteins), annexins (8 proteins), $14-3-3$ proteins 
( 7 proteins), cystatins (6 proteins), and peroxiredoxins ( 5 proteins). Of these families, immunoglobulins had the greatest number of highly-expressed proteins (17 proteins). All identified proteins within these families are listed in Table 4.

Table 4. Major protein families identified in human tear samples.

\begin{tabular}{|c|c|c|c|c|c|c|c|c|}
\hline Families & Group & Count & \multicolumn{6}{|c|}{ Proteins } \\
\hline \multirow{11}{*}{ Immunoglobulin } & \multirow{3}{*}{ High } & \multirow{3}{*}{17} & IGHV4-59 & IGHV5-51 & JCHAIN & IGHA1 & IGHM & $I G K C$ \\
\hline & & & IGKV1D-33 & IGHG2 & IGLV3-9 & IGKV1-8 & IGLC2 & $I G K$ \\
\hline & & & $I G K V 2 D-29$ & IGKV3-15 & IGHV3-7 & IGKV4-1 & IGLL5 & \\
\hline & & 8 & IGA2 & IGKV3-20 & IGHV6-1 & IGG1 & IGHG3 & IGHG4 \\
\hline & Medium & 8 & IGM & IGLV1-47 & & & & \\
\hline & Low & 7 & $\begin{array}{l}I G K V 3 D-11 \\
I G K V 3 D-20\end{array}$ & IGKV3-11 & IGHV3-15 & IGHV3-9 & IGHA2 & IGHG1 \\
\hline & & & IGHV1-69D & IGKV1D-8 & IGHV3-72 & IGHV3-74 & IGHV3-49 & IGHV3-33 \\
\hline & & & IGKV $6 D-21$ & IGLC1 & IGLV1-40 & IGLV1-44 & IGLV6-57 & IGSF22 \\
\hline & Rare & 29 & IGHV3-64D & IGHV1-18 & IGHV2-26 & IGHV3-64 & $I G D$ & IGHV4-28 \\
\hline & & & IGHV5-10-1 & IGKV5-2 & IGKV $3 D-15$ & IGKV1-16 & IGKV1-17 & IGKV1-6 \\
\hline & & & $I G K V 1 D-13$ & IGLV3-19 & IGLL1 & IGSF10 & & \\
\hline \multirow{5}{*}{ Keratin } & High & 7 & $\begin{array}{c}\text { KRT10 } \\
\text { KRT4 }\end{array}$ & KRT9 & KRT1 & KRT2 & KRT13 & KRT19 \\
\hline & Medium & 5 & KRT14 & KRT5 & KRT7 & KRT6A & KRT8 & \\
\hline & Low & 2 & KRT18 & KRT3 & & & & \\
\hline & Rare & 12 & KRT15 & KRT82 & KRT85 & KRT78 & KRT31 & KRT34 \\
\hline & Rare & 12 & KRTAP5-1 & KRT17 & KRT23 & KRT83 & KRT86 & KRT36 \\
\hline \multirow{5}{*}{ Complement } & High & 2 & C3 & $C F B$ & & & & \\
\hline & Medium & 2 & $C 4 A$ & CD55 & & & & \\
\hline & Low & 3 & C1QTNF4 & $C 1 Q B$ & $\mathrm{CFH}$ & & & \\
\hline & Rare & 10 & CFHR1 & C1QTNNF2 & C9 & $C 1 R L$ & C1S & $C 4 B$ \\
\hline & & & & CFHRb & & CR1 & & \\
\hline \multirow{4}{*}{ Myosin } & High & 4 & MYL6 & MYH14 & MYL12A & MYH8 & & \\
\hline & Medium & 1 & MYH9 & & & & & \\
\hline & Low & 3 & MYO3A & MYH13 & MYH10 & & & \\
\hline & Rare & 7 & $\begin{array}{l}\text { MYH15 } \\
\text { MYH7B }\end{array}$ & MYL1 & MYLK4 & $M Y L K$ & MYH2 & MYH7 \\
\hline \multirow{4}{*}{ Apolipoprotein } & High & 2 & APOA1 & $A P O A 2$ & & & & \\
\hline & Medium & 0 & & & & & & \\
\hline & Low & 2 & $A P O D$ & $A P O B$ & & & & \\
\hline & Rare & 7 & $\begin{array}{c}A P O A 4 \\
L P A\end{array}$ & APOC 3 & APOL1 & APOC2 & $A P O E$ & $A P O F$ \\
\hline \multirow{4}{*}{ Heat shock } & High & 4 & HSPA1A & HSPB1 & HSP90AA1 & HSPA8 & & \\
\hline & Medium & 1 & HSPA4 & & & & & \\
\hline & Low & 1 & HSP90AB1 & & & & & \\
\hline & Rare & 4 & HSP90AA2P & HSPA13 & HSPA1L & TRAP1 & & \\
\hline \multirow{4}{*}{ Protein s100 } & High & 4 & S100A11 & S100A4 & S100A8 & S100A9 & & \\
\hline & Medium & 0 & & & & & & \\
\hline & Low & 0 & & & & & & \\
\hline & Rare & 5 & S100A10 & S100A14 & S100A7L2 & S100A2 & S100A7 & \\
\hline \multirow{4}{*}{ Mucin } & High & 1 & MUC5AC & & & & & \\
\hline & Medium & 0 & & & & & & \\
\hline & Low & 1 & MUC16 & & & & & \\
\hline & Rare & 6 & MUC12 & MUC17 & MUC19 & MUC2 & MUC5B & MUC6 \\
\hline \multirow{4}{*}{ Annexin } & High & 5 & ANXA1 & ANXA2 & ANXA5 & ANXA3 & $A N X A 4$ & \\
\hline & Medium & 1 & ANXA11 & & & & & \\
\hline & Low & 0 & $\triangle N I Y \triangle 10$ & $\triangle N Y \triangle A S I$ & & & & \\
\hline & Rare & 2 & ANXA10 & $A N X A 8 L 1$ & & & & \\
\hline \multirow{4}{*}{$14-3-3$} & High & 4 & $Y W H A B$ & $Y W H A Z$ & $Y W H A E$ & SFN & & \\
\hline & Medium & 1 & YWHAG & & & & & \\
\hline & Low & 1 & $Y W H A Q$ & & & & & \\
\hline & Rare & 1 & $Y W H A H$ & & & & & \\
\hline \multirow{4}{*}{ Cystatin } & High & 4 & CSTB & CST3 & CST4 & CST1 & & \\
\hline & Medium & 1 & CST2 & & & & & \\
\hline & Low & 1 & CST5 & & & & & \\
\hline & Rare & 0 & & & & & & \\
\hline \multirow{4}{*}{ Peroxiredoxin } & High & 4 & PRDX1 & PRDX5 & PRDX6 & PRDX2 & & \\
\hline & Medium & 0 & & & & & & \\
\hline & Low & 0 & & & & & & \\
\hline & Rare & 1 & PRDX4 & & & & & \\
\hline
\end{tabular}

2.4. Gene Ontology Analyses of Differentially Expressed Proteins in Tear Fluid

Using in-strip protein digestion and HCD fragmentation, a total of 329 proteins were detected in at least $50 \%$ of the tear samples. Gene ontology (GO) analysis was performed to 
determine biological processes, cellular compartments, and molecular functions associated with these proteins. The most highly enriched GO terms are displayed in Table 5.

Table 5. Gene Ontology (GO) enrichment analysis of selected tear proteins.

\begin{tabular}{|c|c|c|c|}
\hline GO ID & GO Term & \# of Proteins & $p$-Value \\
\hline \multicolumn{4}{|c|}{ Biological Processes } \\
\hline GO:0052548 & Regulation of endopeptidase activity & 42 & $1.43 \times 10^{-22}$ \\
\hline GO:0006508 & Proteolysis & 79 & $3.50 \times 10^{-20}$ \\
\hline GO:0006950 & Response to stress & 122 & $6.75 \times 10^{-19}$ \\
\hline GO:0051336 & Regulation of hydrolase activity & 58 & $6.83 \times 10^{-19}$ \\
\hline GO:0009605 & Response to external stimulus & 90 & $8.18 \times 10^{-14}$ \\
\hline GO:0006952 & Defense response & 66 & $1.67 \times 10^{-13}$ \\
\hline GO:0007010 & Cytoskeleton organization & 59 & $1.96 \times 10^{-13}$ \\
\hline GO:0042592 & Homeostatic process & 65 & $4.36 \times 10^{-12}$ \\
\hline GO:0010941 & Regulation of cell death & 61 & $8.42 \times 10^{-12}$ \\
\hline GO:0098542 & Defense response to other organism & 44 & $1.09 \times 10^{-09}$ \\
\hline GO:0009617 & Response to bacterium & 35 & $1.21 \times 10^{-09}$ \\
\hline GO:0006915 & Apoptotic process & 62 & $1.26 \times 10^{-09}$ \\
\hline GO:0006954 & Inflammatory response & 36 & $2.09 \times 10^{-09}$ \\
\hline GO:0051050 & Positive regulation of transport & 38 & $4.16 \times 10^{-09}$ \\
\hline GO:0022610 & Biological adhesion & 51 & $1.20 \times 10^{-08}$ \\
\hline GO:0006793 & Phosphorus metabolic process & 76 & $1.41 \times 10^{-08}$ \\
\hline \multicolumn{4}{|c|}{ Cellular Components } \\
\hline GO:0070062 & Extracellular exosome & 224 & $1.41 \times 10^{-152}$ \\
\hline GO:1903561 & Extracellular vesicle & 224 & $1.74 \times 10^{-148}$ \\
\hline GO:0005576 & Extracellular region & 244 & $1.35 \times 10^{-104}$ \\
\hline GO:0072562 & Blood microparticle & 36 & $4.77 \times 10^{-34}$ \\
\hline GO:0101002 & Ficolin-1-rich granule & 34 & $1.36 \times 10^{-27}$ \\
\hline GO:0070161 & Anchoring junction & 55 & $3.09 \times 10^{-21}$ \\
\hline GO:0005764 & Lysosome & 42 & $1.89 \times 10^{-14}$ \\
\hline GO:0005773 & Vacuole & 44 & $6.14 \times 10^{-14}$ \\
\hline GO:0030054 & Cell junction & 70 & $1.84 \times 10^{-11}$ \\
\hline \multicolumn{4}{|c|}{ Molecular Functions } \\
\hline GO:0061135 & Endopeptidase regulator activity & 31 & $2.56 \times 10^{-23}$ \\
\hline GO:0061134 & Peptidase regulator activity & 33 & $3.18 \times 10^{-23}$ \\
\hline GO:0050839 & Cell adhesion molecule binding & 44 & $1.80 \times 10^{-20}$ \\
\hline GO:0045296 & Cadherin binding & 35 & $4.47 \times 10^{-20}$ \\
\hline GO:0030234 & Enzyme regulator activity & 63 & $1.35 \times 10^{-18}$ \\
\hline GO:0008289 & Lipid binding & 36 & $1.77 \times 10^{-09}$ \\
\hline
\end{tabular}

\subsection{Interaction Network Analyses}

The 329 proteins detected in at least $50 \%$ of the tear samples were further analyzed using Ingenuity Pathway Analysis (IPA) to generate interaction networks and visualize major hubs. A total of 29 proteins connected to more than 15 nodes were considered major hubs of the interaction network (Figure 4A). The proteins with the highest level of interaction with other proteins include two 14-3-3 proteins (YWHAZ and YWHAE), fibronectin (FN1), three heat shock proteins (HSPA8, HSPA5, and HSPB1), two annexins (ANXA1 and ANXA2), and alpha-1-antitrypsin (SERPINA1). IPA analyses also revealed four major canonical pathways highly enriched in the tear proteins, including acute phase response signaling, glucocorticoid receptor signaling, LXR/RXR activation, and phagosome formation (Figure 4B-E). 


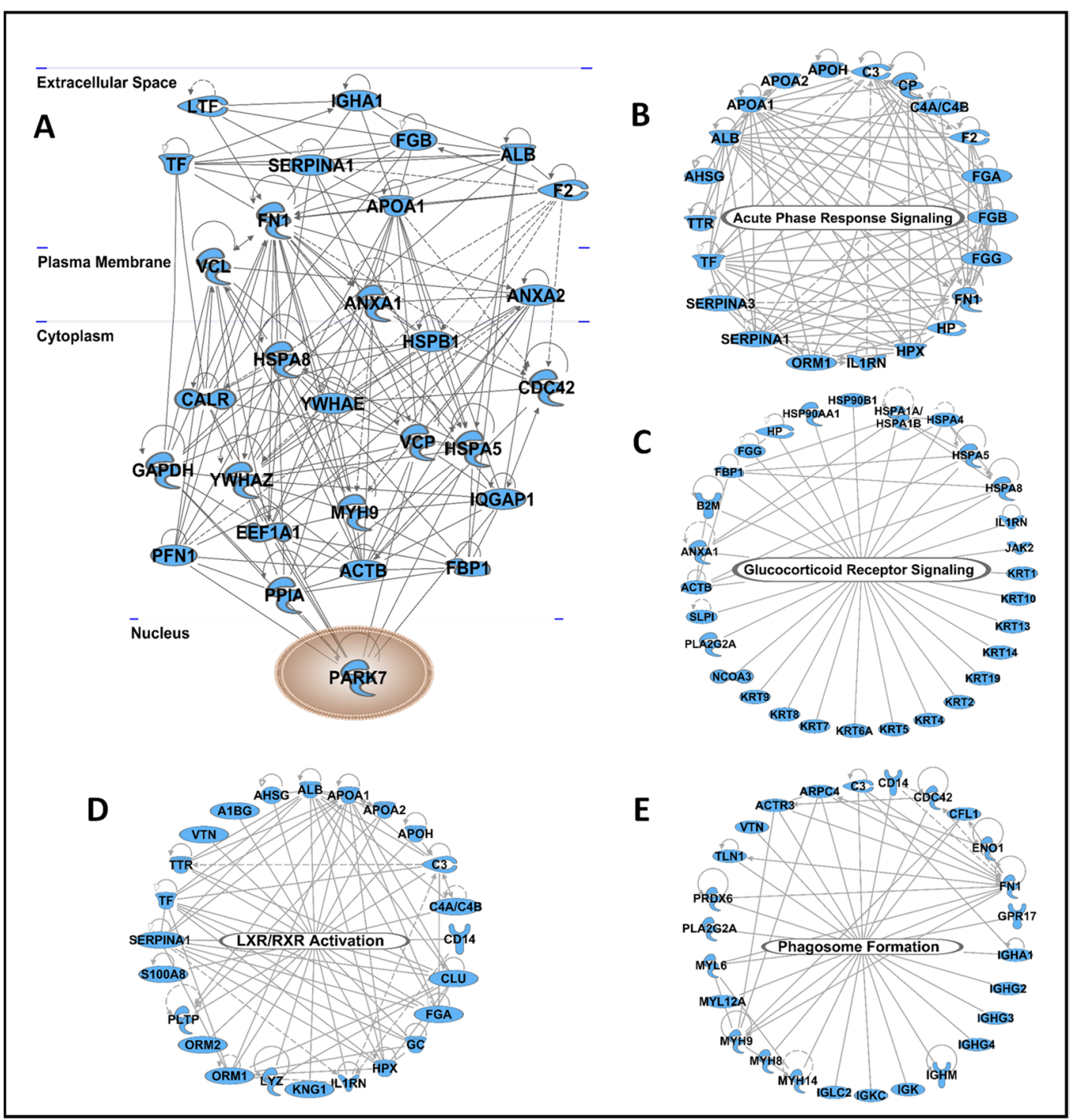

Figure 4. Network analyses revealed tear proteins with the highest level of interactions and four canonical pathways enriched in tear proteins. All 329 proteins detected in at least $50 \%$ of the samples were analyzed using Ingenuity Pathway Analysis software. (A) Proteins that showed the highest level of protein-protein interactions are depicted by cellular location. A total of four canonical pathways were highly enriched in tear proteins, including acute phase response signaling (B), glucocorticoid receptor signaling $(\mathbf{C})$, LXR/RXR signaling (D), and phagosome formation (E).

\section{Discussion}

Advancements in mass spectrometry over the last two decades, including the advent of Orbitrap and higher-energy collision dissociation, have increased yields of proteins and peptides from very small sample volumes, such as tear fluid. In this study, we compared four different workflows, consisting of two digestion and two fragmentation methods, to establish an optimized workflow for the proteomic analysis of human tear samples. While our in-strip protein digestion method produced a clear improvement in the number of identified proteins and peptides compared to pre-extraction digestion, both CID and HCD fragmentation produced nearly identical yields; however, HCD fragmentation provides additional information for identifying and assessing post-translational modifications, such as glycosylation [22]. Given the abundance of glycoproteins in tears [23], as well as the significant roles they play in maintaining ocular surface homeostasis [24], HCD fragmentation combined with in-strip digestion was selected as the optimal workflow for the proteomic analysis of tears; this will facilitate future glycoproteomic studies. 
Using the selected workflow, a total of 3370 unique proteins were identified, with an average of 678 unique proteins per sample. This is an improved and more sensitive detection method compared to previously reported LC-MS/MS methods [17,25-46]. Aass et al. detected an average of 309 proteins per subject (pooling 2 strips collected from both eyes) using the same post-extraction protein digestion method, though only paired with CID fragmentation [29]. It is important to note that our workflow did not involve pooling multiple strips together to increase protein detection. Since ocular surface disorders are not always bilateral and each eye has distinct properties, this allows for the more accurate correlation between disease states and tear proteomic profiles [47]. Thus, our proposed workflow, including our in-strip protein digestion method, can be used in future studies attempting to identify tear proteomic biomarkers in ocular diseases. This is the first step in developing diagnostic and prognostic assays for clinical use.

GO and IPA analyses of data from our chosen workflow identified the most abundant proteins as members of the immunoglobulin, keratin, and complement families. Detecting these protein families in the tear fluid offers potential to identify biomarkers for DED and other ocular surface diseases due to the roles of such proteins in mediating immune function and barrier protection. In particular, immunoglobulins, which play a role in protecting the eye from pathogens, were the most abundant protein family identified in our analyses, with 61 proteins detected in the tear fluid. Immunoglobulin A (IgA) is known to be present in mucous membranes, and its high expression in tears has been consistently reported [48]. IgA is produced by acinar cells of the lacrimal gland before being secreted into the aqueous layer of the tear film, where the antibody acts to neutralize pathogens and prohibit their adhesion and invasion of cells at the ocular surface [49]. A recent study by McKay et al. found that differences in the distribution of immunoglobulin chains within tear fluid is associated with keratoconus, another ocular surface disease [48]. Thus, the diversity of Ig chains that were identified in most samples within this small cohort offers an opportunity for insight into different immune-mediated pathologies of the eye.

Seventeen complement family proteins were also present in the majority of tear samples from our chosen workflow. This finding supports recent evidence that low-level constitutive activation of the complement system is found in the cornea and tears of healthy individuals [50]. While the exact role of the complement system on the ocular surface is unknown, it has been suggested that immune or inflammatory responses may trigger an aggressive complement cascade defense [50]. Given the potential for inflammationmediated damage, the interplay of the complement system on the ocular surface needs to be investigated further.

In addition to immunoregulatory families, the apolipoprotein family was highly represented in tear fluid, with 11 apolipoproteins identified in our analyses. Apolipoproteins $\mathrm{A} 1(A P O A 1)$ and $\mathrm{A} 2$ (APOA2) are produced primarily in the liver and are best known for carrying cholesterol as the constitutive proteins of high-density lipoprotein (HDL) [51,52]. In the meibomian gland, $A P O A 1$ functions to reverse cholesterol transport, preventing the build-up of free cholesterol that can otherwise lead to meibomian gland dysfunction (MGD) [53]. Also, a previous study has shown that $A P O A 2$ is upregulated in the tears of patients with diabetes [54].

Structural proteins of the ocular surface, such as keratins and myosins, are commonly found in tear fluid in both healthy and diseased conditions [55]. Keratins are produced by the meibomian gland and form a protective covering for the eye [56]. Myosins are ubiquitously expressed across cell types, and their cellular functions are diverse, including roles in polarization, movement, and exocytosis [57-59]. Specifically, myosin 6, found in highest abundance, is necessary for iris development [60]. In our analysis of human tear fluid with the chosen workflow, we were able to detect 26 keratin-family proteins and 15 myosin-family proteins.

Consistent with other studies, lactotransferrin (LTF), lipocalin-1 (LCN1), albumin $(A L B)$, and prolactin-inducible protein $(P I P)$ were the top four proteins detected with the highest levels in the tear film [61]. Lactotransferrin is a glycoprotein with iron-chelating 
properties that aid in the defense of the mucosa [62]. However, lactotransferrin has also demonstrated the ability to reduce dry-eye associated inflammation and prevent Herpes Simplex Virus (HSV) infection on the ocular surface [63]. Prolactin-inducible protein plays a role in increasing the placement of aquaporins in the apical cell membrane to provide lubrication to the ocular surface [64]. Lipocalin-1 is found primarily in the outermost lipid layer of the tear film, where it protects against desiccation. Thus, its levels in tear fluid are reduced in patients with deficient lacrimal secretion, such as Sjögren's syndrome and other subtypes of aqueous deficient dry eye [65].

Tear proteins detected with the highest number of protein-protein interactions from IPA include 14-3-3 protein zeta/delta (YWHAZ), fibronectin (FN1), and heat shock protein family A members 8 (HSPA8) and 5 (HSPA5). High expression of the 14-3-3 family has been associated with Sjögren's syndrome, although their exact role in the eye is still unclear [66]. Additionally, the expression of both YWHAZ and HSPA8 has been shown to negatively correlate with fluorescein tear break-up time (FTBUT), suggesting these proteins may play a role in dry eye symptoms [66]. HSPA5 levels have been shown to increase in tears in response to successful glaucoma treatment [66].

Since the tear film is an acellular biofluid, the majority of its protein and lipid contents are secreted by glandular and epithelial cells via exosomes. In our study, extracellular exosome and extracellular vesicle were highly enriched cellular components associated with tear proteins. Four major canonical pathways associated with the identified tear proteins were acute phase response signaling, glucocorticoid receptor signaling, liver $X$ receptor/retinoid $X$ receptor (LXR/RXR) signaling, and phagosome formation. The concentration of acute phase proteins (APPs) has been reported to change in response to inflammation [67]. Furthermore, the APP signaling pathway in the tear film is responsible for initiating immune cascades in the presence of inflammation, thus defining its role in the health of the ocular surface. A previous study found that changes in the tear fluid LXR/RXR signaling pathway are associated with uveitis [68].

Through our comparison of four different workflows, we have successfully identified a sensitive approach for discerning the proteomic profile of human tear fluid. Our findings further our understanding of the tear film by identifying pathways and protein families associated with the healthy tear film and its barrier integrity. Our in-strip protein digestion method coupled with HCD fragmentation may be adopted in future studies of human tear fluid to improve the diagnosis of ocular diseases and discern their underlying mechanisms.

\section{Materials and Methods}

\subsection{Sample Collection}

Tear samples were collected from 11 healthy subjects at the Department of Ophthalmology, Medical College of Georgia at Augusta University. The demographic information of the subjects is shown in Table 1 . The study was approved by the Institutional Review Board at Augusta University (IRB Project ID\# 1458143-12, Approval Date: 13 July 2021). Schirmer strips (TearFlo, HUB Pharmaceuticals, Scottsdale, AZ, USA) were used to collect the tear samples because of their previously reported ability to collect a greater number of unique proteins than capillary tubes [69]. Also, patients generally prefer their use over capillary tubes, as Schirmer strips are safer and perceived as less invasive [18]. First, each Schirmer strip was folded to a $90^{\circ}$ angle at the $0 \mathrm{~mm}$ mark. The rounded end of the strip was inserted into the lateral portion of the lower conjunctival sac of the right eye for $5 \mathrm{~min}$. The subjects' eyes remained closed while the strips were in place. Upon removal, the strips were cut in half lengthwise into two equal pieces, and each half was placed in a separate cryogenic vial (\#5000-0020, Thermo Fisher Scientific, Waltham, MA, USA); each half was used separately for the two protein digestion methods, as described in 4.2. The samples were kept at $-80{ }^{\circ} \mathrm{C}$ until processed further. 


\subsection{Protein Digestion}

Two distinct protein digestion methods were compared. For each strip collected from a single subject, proteins from one half of the Schirmer strip were extracted prior to protein digestion, as previously described (Method A) [29], while the other half was subjected to our newly developed method of in-strip protein digestion (Method B) (Figure 1). Thus, there were 11 biological replicates in each digestion group. For post-extraction protein digestion, $450 \mu \mathrm{L}$ of $100 \mathrm{mM}$ ammonium bicarbonate buffer with $50 \mathrm{mM}$ sodium chloride (SigmaAldrich, St. Louis, MO, USA) was added to the strip and mixed for $4 \mathrm{~h}$ at $25^{\circ} \mathrm{C}$. The samples were then centrifuged in a centrifugal filter unit (\#74-3840, Harvard Apparatus, Holliston, MA, USA) at $7500 \mathrm{rpm}$ for $5 \mathrm{~min}$, after which the strip was removed. The extracted proteins were lyophilized and re-dissolved in $60 \mu \mathrm{L}$ of $8 \mathrm{M}$ urea in $50 \mathrm{mM}$ Tris- $\mathrm{HCl}(\mathrm{pH}$ 8) (SigmaAldrich, St. Louis, MO, USA). For in-strip protein digestion, the Schirmer strip halves were first lyophilized to dryness. Each strip was then cut into $5 \mathrm{~mm} \times 2.5 \mathrm{~mm}$ pieces, and $120 \mu \mathrm{L}$ of $8 \mathrm{M}$ urea in $50 \mathrm{mM}$ Tris- $\mathrm{HCl}(\mathrm{pH} 8)$ was added. Both sets of samples were reduced with $10 \mathrm{mM}$ dithiothreitol, alkylated using $55 \mathrm{mM}$ iodoacetamide and digested using MS-grade trypsin (\#90057, Thermo Scientific, Waltham, MA, USA) at a 1:20 trypsin to protein ratio $(w / w)$ overnight at $37^{\circ} \mathrm{C}$. Digested peptides were cleaned using C18 spin columns (\#744101, Harvard Apparatus, Holliston, MA, USA) and then lyophilized before being analyzed on the Orbitrap Fusion Tribrid mass spectrometer coupled with an Ultimate 3000 nano-UPLC system (Thermo Fisher Scientific, Waltham, MA, USA).

\section{3. $L C-M S / M S$}

Four microliters of reconstituted peptides (in $2 \%$ acetonitrile with $0.1 \%$ formic acid) were loaded and washed on a Pepmap100 C18 trap ( $5 \mu \mathrm{m}, 0.3 \times 5 \mathrm{~mm}$, Thermo Fisher Scientific, Waltham, MA, USA) at $20 \mu \mathrm{L} / \mathrm{min}$ using $2 \%$ acetonitrile in water (with $0.1 \%$ formic acid) for $10 \mathrm{~min}$ and then separated on a Pepmap100 RSLC C18 column $(2.0 \mu \mathrm{m}$, $75 \mu \mathrm{m} \times 150 \mathrm{~mm}$, Thermo Fisher Scientific, Waltham, MA, USA) using a gradient of 2 to $40 \%$ acetonitrile with $0.1 \%$ formic acid over $120 \mathrm{~min}$ at a flow rate of $300 \mathrm{~nL} / \mathrm{min}$ and a column temperature of $40^{\circ} \mathrm{C}$. Eluted peptides were introduced into the Orbitrap Fusion MS via a nano-electrospray ionization source with a temperature of $300{ }^{\circ} \mathrm{C}$ and spray voltage of $2000 \mathrm{~V}$ by data-dependent acquisition in positive mode using Orbitrap MS analyzer for precursor scan at 120,000 FWHM from 400 to $2000 \mathrm{~m} / \mathrm{z}$ and ion-trap MS analyzer for MS/MS scans in top speed mode (3 s cycle time) with dynamic exclusion settings (repeat count 1 , repeat duration $15 \mathrm{~s}$, and exclusion duration $30 \mathrm{~s}$ ). All samples from Method A $(n=11)$ and Method B $(n=11)$ were subjected to LC-MS/MS twice to compare the efficacy of two common fragmentation methods, $\mathrm{CID}$ and $\mathrm{HCD}$, using a normalized collision energy of $30 \%$.

\subsection{Protein Identification and Analysis}

Raw MS data were processed via the Proteome Discoverer software (version 2.2, Thermo Fisher Scientific, Waltham, MA, USA) and submitted for SequestHT search against the SwissProt human database. SequestHT search parameters were set as $10 \mathrm{ppm}$ precursor and 0.6 Da product ion tolerance with static carbidomethylation $(+57.021 \mathrm{Da})$ for cysteine and dynamic oxidation for methionine $(+15.995 \mathrm{Da})$. The percolator peptide-spectrum matching (PSM) validator algorithm was used for PSM validation. Proteins unable to be distinguished based on the database search results were grouped to satisfy the principles of parsimony. A protein report was generated containing the identities and number of PSM for each protein group, which were further utilized for spectral counting based semi-quantitative analysis.

\subsection{Statistical Analysis}

The average protein and peptide counts per sample identified in all four workflows were compared via two-way ANOVA, and subsequent pairwise comparisons were performed using Tukey's multiple comparison test in order to control the family wise error 
rate [70]. The PSM values generated from LC-MS/MS analysis were $\log 2$ transformed to remove skewness. Proteins were allocated into groups using their mean expression level and detection in a proportion of samples. The ubiquitous proteins (detected in more than $50 \%$ of samples) were examined in further detail. The proteins were associated with biological processes, molecular functions, and cellular components using gene ontology (GO) enrichment analyses. All statistical analyses were performed using R version 4.0.3. Further, network analyses were performed using Ingenuity Pathway Analysis (IPA) to visualize the interactions between these proteins and identify the major hubs.

\section{Conclusions}

Multiple studies have shown the potential of tear proteomics for the discovery of diagnostic and prognostic biomarkers of several ocular and systemic diseases, including dry eye disease, pterygium, keratoconus, glaucoma, diabetic retinopathy, cancer, systemic sclerosis, and cystic fibrosis [20,71-73]. Due to its wide array of possible applications, an optimized workflow for tear processing holds immense translational potential. In this study, we have compared different mass spectrometry workflows and established a more sensitive and reliable method of tear protein detection and analysis that can be used for future tear proteomic biomarker research.

Author Contributions: Conceptualization, G.J., S.S. and A.S.; Data curation, G.J. and T.J.L.; Formal analysis, T.J.L. and A.S.; Funding acquisition, A.S.; Investigation, S.S.; Methodology, G.J., T.J.L., J.G., G.R. and W.Z.; Project administration, A.S.; Resources, L.U., A.E., M.S., W.Z. and S.S.; Software, T.J.L.; Supervision, A.S.; Visualization, T.J.L. and J.G.; Writing-original draft, G.J. and G.R.; Writingreview and editing, L.U., S.S. and A.S. All authors have read and agreed to the published version of the manuscript.

Funding: This research was funded by the National Institutes of Health, National Eye Institute (Bethesda, MD, USA) grant\# R01 EY029728 awarded to Ashok Sharma, and grant\# P30 EY031631 Center Core Grant for Vision Research.

Institutional Review Board Statement: The study was conducted in accordance with the Declaration of Helsinki and approved by the Institutional Review Board of Augusta University (IRB Project ID\# 1458143-12, Approval Date: 13 July 2021).

Informed Consent Statement: Informed consent was obtained from all subjects involved in the study.

Data Availability Statement: The mass spectrometry proteomics data have been deposited to the ProteomeXchange Consortium via the PRIDE partner repository with the dataset identifier PXD030990).

Conflicts of Interest: The authors declare no conflict of interest.

\section{References}

1. Argüeso, P. The Disrupted Glycocalyx as a Source of Ocular Surface Biomarkers. Eye Contact Lens 2020, 46, S53. [CrossRef] [PubMed]

2. Cher, I. A new look at lubrication of the ocular surface: Fluid mechanics behind the blinking eyelids. Ocul. Surf. 2008, 6, 79-86. [CrossRef]

3. Willcox, M.D.; Argüeso, P.; Georgiev, G.A.; Holopainen, J.M.; Laurie, G.W.; Millar, T.J.; Papas, E.B.; Rolland, J.P.; Schmidt, T.A.; Stahl, U. TFOS DEWS II tear film report. Ocul. Surf. 2017, 15, 366-403. [CrossRef]

4. $\quad$ Lindén, S.K.; Sheng, Y.H.; Every, A.L.; Miles, K.M.; Skoog, E.C.; Florin, T.H.; Sutton, P.; McGuckin, M.A. MUC1 limits Helicobacter pylori infection both by steric hindrance and by acting as a releasable decoy. PLoS Pathog. 2009, 5, e1000617. [CrossRef] [PubMed]

5. Menon, N.G.; Goyal, R.; Lema, C.; Woods, P.S.; Tanguay, A.P.; Morin, A.A.; Das, N.; Jay, G.D.; Krawetz, R.J.; Dufour, A Proteoglycan 4 (PRG4) expression and function in dry eye associated inflammation. Exp. Eye Res. 2021, 208, 108628. [CrossRef]

6. Nair, A.P.; D’Souza, S.; Shetty, R.; Ahuja, P.; Kundu, G.; Khamar, P.; Dadachanji, Z.; Paritekar, P.; Patel, P.; Dickman, M.M. Altered ocular surface immune cell profile in patients with dry eye disease. Ocul. Surf. 2021, 21, 96-106. [CrossRef] [PubMed]

7. Pflugfelder, S.C.; Jones, D.; Ji, Z.; Afonso, A.; Monroy, D. Altered cytokine balance in the tear fluid and conjunctiva of patients with Sjögren's syndrome keratoconjunctivitis sicca. Curr. Eye Res. 1999, 19, 201-211. [CrossRef]

8. Shtein, R.M. Post-LASIK dry eye. Expert Rev. Ophthalmol. 2011, 6, 575-582. [CrossRef]

9. Argüeso, P.; Balaram, M.; Spurr-Michaud, S.; Keutmann, H.T.; Dana, M.R.; Gipson, I.K. Decreased levels of the goblet cell mucin MUC5AC in tears of patients with Sjogren syndrome. Investig. Ophthalmol. Vis. Sci. 2002, 43, 1004-1011. 
10. Shimazaki-Den, S.; Dogru, M.; Higa, K.; Shimazaki, J. Symptoms, visual function, and mucin expression of eyes with tear film instability. Cornea 2013, 32, 1211-1218. [CrossRef]

11. Bron, A.J.; Tomlinson, A.; Foulks, G.N.; Pepose, J.S.; Baudouin, C.; Geerling, G.; Nichols, K.K.; Lemp, M.A. Rethinking dry eye disease: A perspective on clinical implications. Ocul. Surf. 2014, 12, S1-S31. [CrossRef] [PubMed]

12. Sullivan, B.D.; Crews, L.A.; Messmer, E.M.; Foulks, G.N.; Nichols, K.K.; Baenninger, P.; Geerling, G.; Figueiredo, F.; Lemp, M.A. Correlations between commonly used objective signs and symptoms for the diagnosis of dry eye disease: Clinical implications. Acta Ophthalmol. 2014, 92, 161-166. [CrossRef] [PubMed]

13. Pflugfelder, S.C.; Solomon, A.; Stern, M.E. The diagnosis and management of dry eye: A twenty-five-year review. Cornea 2000, 19, 644-649. [CrossRef] [PubMed]

14. Chiva, A. Tear biomarkers in dry eye disease. Eur. Ophthalmic Rev. 2019, 13, 21-26. [CrossRef]

15. Li, B.; Sheng, M.; Li, J.; Yan, G.; Lin, A.; Li, M.; Wang, W.; Chen, Y. Tear proteomic analysis of Sjögren syndrome patients with dry eye syndrome by two-dimensional-nano-liquid chromatography coupled with tandem mass spectrometry. Sci. Rep. 2014, 4, 5772. [CrossRef] [PubMed]

16. Jung, J.H.; Ji, Y.W.; Hwang, H.S.; Oh, J.W.; Kim, H.C.; Lee, H.K.; Kim, K.P. Proteomic analysis of human lacrimal and tear fluid in dry eye disease. Sci. Rep. 2017, 7, 13363. [CrossRef]

17. Ponzini, E.; Santambrogio, C.; De Palma, A.; Mauri, P.; Tavazzi, S.; Grandori, R. Mass spectrometry-based tear proteomics for noninvasive biomarker discovery. Mass Spectrom. Rev. 2021. [CrossRef]

18. Posa, A.; Bräuer, L.; Schicht, M.; Garreis, F.; Beileke, S.; Paulsen, F. Schirmer strip vs. capillary tube method: Non-invasive methods of obtaining proteins from tear fluid. Ann. Anat.-Anat. Anz. 2013, 195, 137-142. [CrossRef]

19. Makarov, A. Orbitrap journey: Taming the ion rings. Nat. Commun. 2019, 10, 3743. [CrossRef]

20. Ma, J.Y.W.; Sze, Y.H.; Bian, J.F.; Lam, T.C. Critical role of mass spectrometry proteomics in tear biomarker discovery for multifactorial ocular diseases. Int. J. Mol. Med. 2021, 47, 83. [CrossRef]

21. Doll, S.; Burlingame, A.L. Mass spectrometry-based detection and assignment of protein posttranslational modifications. ACS Chem. Biol. 2015, 10, 63-71. [CrossRef] [PubMed]

22. Xiao, H.; Sun, F.; Suttapitugsakul, S.; Wu, R. Global and site-specific analysis of protein glycosylation in complex biological systems with Mass Spectrometry. Mass Spectrom. Rev. 2019, 38, 356-379. [CrossRef] [PubMed]

23. Lei, Z.; Beuerman, R.W.; Chew, A.P.; Koh, S.K.; Cafaro, T.A.; Urrets-Zavalia, E.A.; Urrets-Zavalia, J.A.; Li, S.F.; Serra, H.M Quantitative analysis of N-linked glycoproteins in tear fluid of climatic droplet keratopathy by glycopeptide capture and iTRAQ. J. Proteome Res. 2009, 8, 1992-2003. [CrossRef] [PubMed]

24. Rodriguez Benavente, M.C.; Argueso, P. Glycosylation pathways at the ocular surface. Biochem. Soc. Trans. 2018, 46, 343-350. [CrossRef]

25. Huang, Z.; Du, C.X.; Pan, X.D. The use of in-strip digestion for fast proteomic analysis on tear fluid from dry eye patients. PLoS ONE 2018, 13, e0200702. [CrossRef] [PubMed]

26. Li, N.; Wang, N.; Zheng, J.; Liu, X.M.; Lever, O.W.; Erickson, P.M.; Li, L. Characterization of human tear proteome using multiple proteomic analysis techniques. J. Proteome Res. 2005, 4, 2052-2061. [CrossRef]

27. De Souza, G.A.; Godoy, L.M.; Mann, M. Identification of 491 proteins in the tear fluid proteome reveals a large number of proteases and protease inhibitors. Genome Biol. 2006, 7, R72. [CrossRef]

28. Zhou, L.; Zhao, S.Z.; Koh, S.K.; Chen, L.; Vaz, C.; Tanavde, V.; Li, X.R.; Beuerman, R.W. In-depth analysis of the human tear proteome. J. Proteom. 2012, 75, 3877-3885. [CrossRef]

29. Aass, C.; Norheim, I.; Eriksen, E.F.; Thorsby, P.M.; Pepaj, M. Single unit filter-aided method for fast proteomic analysis of tear fluid. Anal. Biochem. 2015, 480, 1-5. [CrossRef]

30. Dor, M.; Eperon, S.; Lalive, P.H.; Guex-Crosier, Y.; Hamedani, M.; Salvisberg, C.; Turck, N. Investigation of the global protein content from healthy human tears. Exp. Eye Res. 2019, 179, 64-74. [CrossRef]

31. Winiarczyk, M.; Kaarniranta, K.; Winiarczyk, S.; Adaszek, L.; Winiarczyk, D.; Mackiewicz, J. Tear film proteome in age-related macular degeneration. Graefes Arch. Clin. Exp. Ophthalmol. 2018, 256, 1127-1139. [CrossRef] [PubMed]

32. Aluru, S.V.; Shweta, A.; Bhaskar, S.; Geetha, K.; Sivakumar, R.M.; Utpal, T.; Padmanabhan, P.; Angayarkanni, N. Tear Fluid Protein Changes in Dry Eye Syndrome Associated with Rheumatoid Arthritis: A Proteomic Approach. Ocul. Surf. 2017, 15, 112-129. [CrossRef]

33. Versura, P.; Nanni, P.; Bavelloni, A.; Blalock, W.L.; Piazzi, M.; Roda, A.; Campos, E.C. Tear proteomics in evaporative dry eye disease. Eye 2010, 24, 1396-1402. [CrossRef]

34. Zhou, L.; Beuerman, R.W.; Chan, C.M.; Zhao, S.Z.; Li, X.R.; Yang, H.; Tong, L.; Liu, S.; Stern, M.E.; Tan, D. Identification of tear fluid biomarkers in dry eye syndrome using iTRAQ quantitative proteomics. J. Proteome Res. 2009, 8, 4889-4905. [CrossRef]

35. Soria, J.; Duran, J.A.; Etxebarria, J.; Merayo, J.; Gonzalez, N.; Reigada, R.; Garcia, I.; Acera, A.; Suarez, T. Tear proteome and protein network analyses reveal a novel pentamarker panel for tear film characterization in dry eye and meibomian gland dysfunction. J. Proteom. 2013, 78, 94-112. [CrossRef] [PubMed]

36. Csosz, E.; Boross, P.; Csutak, A.; Berta, A.; Toth, F.; Poliska, S.; Torok, Z.; Tozser, J. Quantitative analysis of proteins in the tear fluid of patients with diabetic retinopathy. J. Proteom. 2012, 75, 2196-2204. [CrossRef]

37. Kuo, M.T.; Fang, P.C.; Chao, T.L.; Chen, A.; Lai, Y.H.; Huang, Y.T.; Tseng, C.Y. Tear Proteomics Approach to Monitoring Sjogren Syndrome or Dry Eye Disease. Int. J. Mol. Sci. 2019, 20, 1932. [CrossRef] [PubMed] 
38. Kim, H.J.; Kim, P.K.; Yoo, H.S.; Kim, C.W. Comparison of tear proteins between healthy and early diabetic retinopathy patients. Clin. Biochem. 2012, 45, 60-67. [CrossRef] [PubMed]

39. Pieragostino, D.; Bucci, S.; Agnifili, L.; Fasanella, V.; D’Aguanno, S.; Mastropasqua, A.; Ciancaglini, M.; Mastropasqua, L.; Di Ilio, C.; Sacchetta, P.; et al. Differential protein expression in tears of patients with primary open angle and pseudoexfoliative glaucoma. Mol. Biosyst. 2012, 8, 1017-1028. [CrossRef] [PubMed]

40. Pieragostino, D.; Agnifili, L.; Fasanella, V.; D’Aguanno, S.; Mastropasqua, R.; Di Ilio, C.; Sacchetta, P.; Urbani, A.; Del Boccio, P. Shotgun proteomics reveals specific modulated protein patterns in tears of patients with primary open angle glaucoma naive to therapy. Mol. Biosyst. 2013, 9, 1108-1116. [CrossRef] [PubMed]

41. Nattinen, J.; Jylha, A.; Aapola, U.; Parkkari, M.; Mikhailova, A.; Beuerman, R.W.; Uusitalo, H. Patient stratification in clinical glaucoma trials using the individual tear proteome. Sci. Rep. 2018, 8, 12038. [CrossRef]

42. Acera, A.; Vecino, E.; Rodriguez-Agirretxe, I.; Aloria, K.; Arizmendi, J.M.; Morales, C.; Duran, J.A. Changes in tear protein profile in keratoconus disease. Eye 2011, 25, 1225-1233. [CrossRef] [PubMed]

43. Pannebaker, C.; Chandler, H.L.; Nichols, J.J. Tear proteomics in keratoconus. Mol. Vis. 2010, 16, 1949-1957.

44. Yenihayat, F.; Altintas, O.; Kasap, M.; Akpinar, G.; Guzel, N.; Celik, O.S. Comparative proteome analysis of the tear samples in patients with low-grade keratoconus. Int. Ophthalmol. 2018, 38, 1895-1905. [CrossRef] [PubMed]

45. Kishazi, E.; Dor, M.; Eperon, S.; Oberic, A.; Hamedani, M.; Turck, N. Thyroid-associated orbitopathy and tears: A proteomics study. J. Proteom. 2018, 170, 110-116. [CrossRef]

46. Jiang, L.; Rong, A.; Wei, R.; Diao, J.; Ding, H.; Wang, W. Tear proteomics of orbital decompression for disfiguring exophthalmos in inactive thyroid-associated ophthalmopathy. Exp. Ther. Med. 2020, 20, 253. [CrossRef] [PubMed]

47. Potvin, R.; Makari, S.; Rapuano, C.J. Tear film osmolarity and dry eye disease: A review of the literature. Clin. Ophthalmol. 2015, 9 , 2039-2047. [CrossRef]

48. McKay, T.B.; Serjersen, H.; Hjortdal, J.; Zieske, J.D.; Karamichos, D. Characterization of Tear Immunoglobulins in a Small-Cohort of Keratoconus Patients. Sci. Rep. 2020, 10, 9426. [CrossRef]

49. Janssen, P.T.; van Bijsterveld, O.P. Origin and biosynthesis of human tear fluid proteins. Invest. Ophthalmol. Vis. Sci. 1983, 24, 623-630.

50. Jha, P.; Bora, P.S.; Bora, N.S. The role of complement system in ocular diseases including uveitis and macular degeneration. Mol. Immunol. 2007, 44, 3901-3908. [CrossRef]

51. Gordon, S.M.; Hofmann, S.; Askew, D.S.; Davidson, W.S. High density lipoprotein: It's not just about lipid transport anymore Trends Endocrinol. Metab. TEM 2011, 22, 9-15. [CrossRef] [PubMed]

52. Pownall, H.J. Rethinking apolipoprotein A-II in lipid metabolism. Am. J. Clin. Nutr. 2018, 108, 4-5. [CrossRef] [PubMed]

53. Nyunt, A.K.; Ishida, Y.; Yu, Y.; Shimada, S. Topical apolipoprotein A-1 may have a beneficial effect on the corneal epithelium in a mouse model of dry eye: A pilot study. Eye Contact Lens 2008, 34, 287-292. [CrossRef]

54. Li, B.; Sheng, M.; Xie, L.; Liu, F.; Yan, G.; Wang, W.; Lin, A.; Zhao, F.; Chen, Y. Tear proteomic analysis of patients with type 2 diabetes and dry eye syndrome by two-dimensional nano-liquid chromatography coupled with tandem mass spectrometry. Invest. Ophthalmol. Vis. Sci. 2014, 55, 177-186. [CrossRef] [PubMed]

55. Palaniappan, C.K.; Schütt, B.S.; Bräuer, L.; Schicht, M.; Millar, T.J. Effects of Keratin and Lung Surfactant Proteins on the Surface Activity of Meibomian Lipids. Investig. Ophthalmol. Vis. Sci. 2013, 54, 2571-2581. [CrossRef]

56. Jester, J.V.; Parfitt, G.J.; Brown, D.J. Meibomian gland dysfunction: Hyperkeratinization or atrophy? BMC Ophthalmol. 2015, 15 (Suppl. 1), 156. [CrossRef]

57. Sellers, J.R. Myosins: A diverse superfamily. Biochim. Biophys. Acta 2000, 1496, 3-22. [CrossRef]

58. Rudolf, R.; Bittins, C.M.; Gerdes, H.H. The role of myosin V in exocytosis and synaptic plasticity. J. Neurochem. 2011, 116, 177-191. [CrossRef]

59. Papadopulos, A. Membrane shaping by actin and myosin during regulated exocytosis. Mol. Cell. Neurosci. 2017, 84, 93-99. [CrossRef]

60. Samuels, I.S.; Bell, B.A.; Sturgill-Short, G.; Ebke, L.A.; Rayborn, M.; Shi, L.; Nishina, P.M.; Peachey, N.S. Myosin 6 is required for iris development and normal function of the outer retina. Invest. Ophthalmol. Vis. Sci. 2013, 54, 7223-7233. [CrossRef]

61. Perumal, N.; Funke, S.; Pfeiffer, N.; Grus, F.H. Proteomics analysis of human tears from aqueous-deficient and evaporative dry eye patients. Sci. Rep. 2016, 6, 29629. [CrossRef]

62. Artym, J. The role of lactoferrin in the iron metabolism. Part II. Antimicrobial and antiinflammatory effect of lactoferrin by chelation of iron. Postepy Hig. Med. Dosw. Online 2010, 64, 604-616. [PubMed]

63. Vagge, A.; Senni, C.; Bernabei, F.; Pellegrini, M.; Scorcia, V.; Traverso, C.E.; Giannaccare, G. Therapeutic Effects of Lactoferrin in Ocular Diseases: From Dry Eye Disease to Infections. Int. J. Mol. Sci. 2020, 21, 6668. [CrossRef] [PubMed]

64. Masoudi, S.; Stapleton, F.J.; Willcox, M.D. Contact Lens-Induced Discomfort and Protein Changes in Tears. Optom. Vis. Sci. Off. Publ. Am. Acad. Optom. 2016, 93, 955-962. [CrossRef]

65. Glasgow, B.J.; Gasymov, O.K. Focus on Molecules: Tear lipocalin. Exp. Eye Res. 2011, 92, 242-243. [CrossRef]

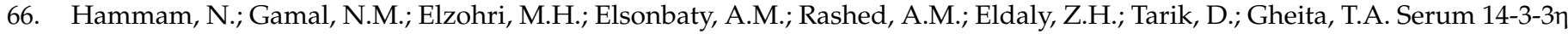
protein is associated with clinical and serologic features of Sjögren's syndrome in patients with systemic lupus erythematosus: A cross-sectional analysis. Clin. Rheumatol. 2020, 39, 2603-2610. [CrossRef]

67. Engler, R. Acute-phase proteins in inflammation. Comptes Rendus Seances Soc. Biol. Ses Fil. 1995, 189, 563-578. 
68. Eidet, J.R.; Jørstad, Ø.K.; Fostad, I.G.; Olstad, O.K.; Sørland, R.Ø.; Moe, M.C.; Petrovski, G.; Pepaj, M. Unilateral acute anterior uveitis is associated with ipsilateral changes in the tear fluid proteome that involves the LXR/RXR pathway. J. Ophthalmic Inflamm. Infect. 2020, 10, 13. [CrossRef]

69. Nattinen, J.; Aapola, U.; Jylha, A.; Vaajanen, A.; Uusitalo, H. Comparison of Capillary and Schirmer Strip Tear Fluid Sampling Methods Using SWATH-MS Proteomics Approach. Transl. Vis. Sci. Technol. 2020, 9, 16. [CrossRef]

70. Tukey, J.W. Exploratory Data Analysis; Addison-Wesley: Boston, MA, USA, 1977; Volume 2.

71. Hagan, S.; Martin, E.; Enríquez-de-Salamanca, A. Tear fluid biomarkers in ocular and systemic disease: Potential use for predictive, preventive and personalised medicine. EPMA J. 2016, 7, 15. [CrossRef] [PubMed]

72. De Almeida Borges, D.; Alborghetti, M.R.; Franco Paes Leme, A.; Ramos Domingues, R.; Duarte, B.; Veiga, M.; Trindade Ferrer, M.; Viana Wanzeler, A.C.; Leite Arieta, C.E.; Alves, M. Tear proteomic profile in three distinct ocular surface diseases: Keratoconus, pterygium, and dry eye related to graft-versus-host disease. Clin. Proteom. 2020, 17, 42. [CrossRef] [PubMed]

73. Wong, T.T.; Zhou, L.; Li, J.; Tong, L.; Zhao, S.Z.; Li, X.R.; Yu, S.J.; Koh, S.K.; Beuerman, R.W. Proteomic profiling of inflammatory signaling molecules in the tears of patients on chronic glaucoma medication. Invest. Ophthalmol. Vis. Sci. 2011, 52, 7385-7391. [CrossRef] [PubMed] 